\title{
GDF2 Gene
}

National Cancer Institute

\section{Source}

National Cancer Institute. GDF2 Gene. NCI Thesaurus. Code C126995.

This gene is involved in the inhibition of angiogenesis. 